INSTITUTO SUPERIOR ANÍSIO TEIXEIRA

Ellen Carolina Vieira de Simas

\title{
GAMIFICAÇÃO: AS CONTRIBUIÇÕES QUE OS GAMES TRAZEM PARA O AMBIENTE DE APRENDIZADO
}

São Gonçalo

2019 


\section{GAMIFICAÇÃO: AS CONTRIBUIÇÕES QUE OS GAMES TRAZEM PARA O AMBIENTE DE APRENDIZADO}

Monografia apresentada ao curso de Licenciatura em Letras Português-Inglês do Instituto Superior Anísio Teixeira - ISAT como requisito parcial à obtenção do título Licenciado em Letras Português-Inglês.

Orientador: Prof. MSc. Luiz Claudio M. Biagiotti

São Gonçalo 


\section{GAMIFICAÇÃO: AS CONTRIBUIÇÕES QUE OS GAMES TRAZEM PARA O AMBIENTE DE APRENDIZADO}

Monografia apresentada ao curso de Licenciatura em Letras Português-Inglês do Instituto Superior Anísio Teixeira - ISAT como requisito parcial à obtenção do título Licenciado em Letras Português-Inglês.

Orientador: Prof. MSc. Luiz Claudio M. Biagiotti

Luiz Claudio M. Biagiotti - ISAT

São Gonçalo, 10 de junho de 2019. 
DEDICATÓRIA

Dedicado a Michonne e Negan, meus "filhos" de quatro patas e sete vidas. 


\section{AGRADECIMENTOS}

Agradeço aos meus pais Jonas Simas Filho e Alba Simas, a quem devo minha existência, por terem me munido de tantas oportunidades e por viabilizarem tantos klapaucius $^{1}$ ao longo da minha vida. Obrigada pela paciência de esperar tantos anos até que eu finalmente parasse pra escrever este trabalho.

Agradeço a minha irmã mais nova, Amanda Simas, por ter me incentivado a escrever sobre games (um assunto que nos interessa igualmente) e por ter acreditado que eu conseguiria fazê-lo satisfatoriamente. A minha irmã mais velha, Debora Simas, por sempre me inspirar como professora e me mostrar que posso ser uma versão aprimorada de mim mesma.

Agradeço ao meu orientador Claudio Biagiotti pela paciência infinita, por todos as aulas no laboratório - onde plantou em mim a semente da satisfação ao ajudar os colegas ao longo da minha jornada no ensino superior - e por me receber tão bem na primeira aula, do primeiro dia de faculdade, lá em 2011.

Ao professor José Manuel Silva por ter me dando tantos insights e por sempre exigir não menos que o meu melhor.

A professora Lucia Helena Manna pela oportunidade de trabalharmos lado a lado durante a monitoria no curso de Redação para a Comunidade e por todo carinho que teve comigo.

Ao coordenador Flavio Barreto que me tranquilizou e, em 6 de abril de 2018, fez com que eu me desse conta de que a inspiração viria naturalmente após a leitura de todos os textos que eu selecionasse. Apesar de ser algo tão elementar, demorei 8 anos para enxergar isso.

Agradeço, por fim, ao meu marido Allan Gomes por sempre crer em meu potencial (até quando eu mesma não o fiz), por ser tão amável e por trazer calmaria à tempestade que é a minha mente.

1 Código em (primeiros jogos da série) The Sims que fazia com que o jogador - como num passe de mágica adquirisse dinheiro. 
"Um explorador famoso uma vez disse que o extraordinário está no que fazemos, não no que somos. Eu finalmente parti para deixar minha marca, encontrar aventura. No entanto, foi a aventura que me encontrou. Em nossos momentos mais sombrios, quando a vida passa diante dos nossos olhos, encontramos algo. Algo que nos faz continuar seguindo. Algo que nos impulsiona."

(CROFT, Lara. TOMB RAIDER, 2013) 


\section{RESUMO}

Este trabalho busca mostrar, aos interessados no estudo da Gamificação, uma análise de textos acadêmicos sobre o tema. São feitas comparações entre pontos positivos e negativos da utilização de jogos na sala de aula e buscou-se responder quais contribuições a Gamificação traz para o ambiente de aprendizado.

Palavras-chave: gamificação. jogos na educação. nativos digitais. 


\begin{abstract}
This work attempted to analyze academic works about Gamification, which can be of use to anyone who might be interested in the study of this subject. Comparisons are made between pros and cons of the use of games in the classroom, and the work tried to identify which contributions Gamification can bring to the learning environment.
\end{abstract}

Key words: gamification. games in education. digital natives. 


\section{LISTA DE FIGURAS}

FIGURA $1-$ Elementos comuns dos jogos ............................... 12

FIGURA $2-$ Super Mario Bros. $^{\text {TM }}(1985)$.............................. 14

FIGURA $3-$ Elementos da gamificação ..................................... 15

FIGURA $4 \quad-\quad$ Representação de Pong (1972) ............................. 18

FIGURA $5 \quad-\quad$ Modelo de Keller ............................................. 21

FIGURA $6 \quad-$ Tipos de jogadores ...................................... 23

FIGURA $7-$ Pensamentos de cada tipo de jogador ....................... 24

FIGURA $8 \quad-\quad$ Verbos de engajamento social e ação ....................... 25

FIGURA $9-$ Desenvolvimento dos Nativos Digitais .................... 27

FIGURA $10-$ Equipamentos familiares ................................... 28

FIGURA $11-$ Itens a levar em consideração ........................... 31

FIGURA 12 - Conceito moderno de educação ............................. 33 


\section{SUMÁRIO}

1 INTRODUÇÃO

2 A GÊNESE DOS JOGOS

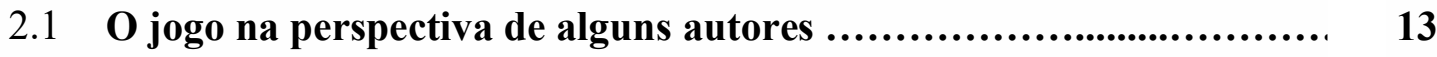

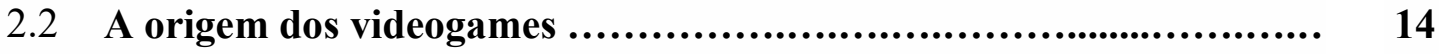

3 O QUE É GAMIFICAÇÃ̃O? ........................................ 18

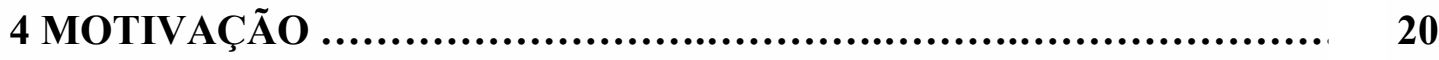

5 ENGAJAMENTO ......................................................... 22

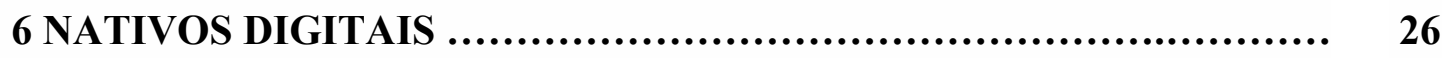

6.1 Ambiente de aprendizagem escolar .................................... 28

6.2 Dinâmica de sala de aula tradicional ..................................... 29

6.3 Dinâmica de sala de aula para nativos digitais ........................ 30

7 DAS IMPLICAÇÕES NA APLICAÇÃO DA GAMIFICAÇÃO .......... 31

$7.1 \quad$ Aspectos negativos .................................................... 31

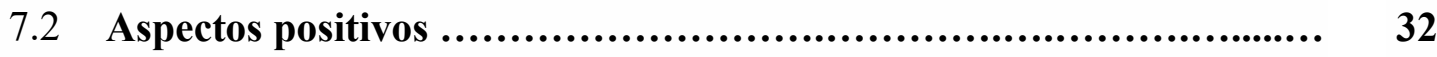

8 CONCLUSÃO

REFERÊNCIAS BIBLIOGRÁFICAS ..................................... 35 


\section{INTRODUÇÃO}

"É necessário fortaleza pra exercer a profissão de educador." (informação verbal) $)^{2}$.

O mundo mudou. A maneira como interagimos, nos comunicamos e aprendemos é, hoje, imediatista e somos ávidos por informação. Vivemos a era dos - que Marc Prensky ${ }^{3}$ chama de - nativos digitais e nunca foi tão fácil ter acesso ao conhecimento e a informação. Podemos visitar bibliotecas em outros países sem sair do lugar, nos graduar em faculdade à distância e nos comunicar em tempo real a um custo relativamente baixo com qualquer pessoa ao redor de todo o globo.

A escola no Brasil segue ainda um modelo tradicional de ensino que está desalinhada com os anseios e a "realidade fora de sala" dos alunos nativos digitais, o que os leva a não conseguir associar modernidade e escola, e consequentemente: aprendizado e dinâmica. Poderiam os jogos melhorar a forma como se aprende e ensina? É possível e benéfico dinamizar a sala de aula e adequá-la às expectativas destes nativos digitais?

Este trabalho busca entender - por meio de pesquisa bibliográfica - o que é a gamificação e analisar se a mesma pode ser vantajosa para o aprendizado dos alunos nativos digitais, seguido das conclusões do trabalho.

\footnotetext{
${ }^{2}$ Fragmento do discurso de Helter Jeronymo L. Barcellos durante palestra do ISAT, em São Gonçalo, em outubro de 2013.

${ }^{3}$ Escritor e palestrante estadunidense - alma mater na Yale University, Harvard Business School e Oberlin College - conhecido como o inventor e propagador dos termos "nativo digital" e "imigrante digital".
} 


\section{A GÊNESE DOS JOGOS}

A palavra jogo vem do latim jocus, significa brincadeira, divertimento. Arqueólogos afirmam ter encontrado registros da presença de jogos e competições desde o período Neolítico, porém não é possível ter certeza dessas interpretações e muitos pesquisadores as consideram especulação. No entanto, um fato inegável e comprovado é que os jogos estão presentes em todas culturas humanas. Mancala, do árabe naqala, que significa mover, por exemplo, é um estilo de jogo já existente há pelo menos 1300 anos. Jogos de tabuleiro, com excessão dos povos esquimós e aborígenes australianos, possuem registro de existência em todo o planeta.

Em geral, jogos possuem sete características, apresentadas na Figura 1, são elas:

Figura 1 - Elementos comuns dos jogos

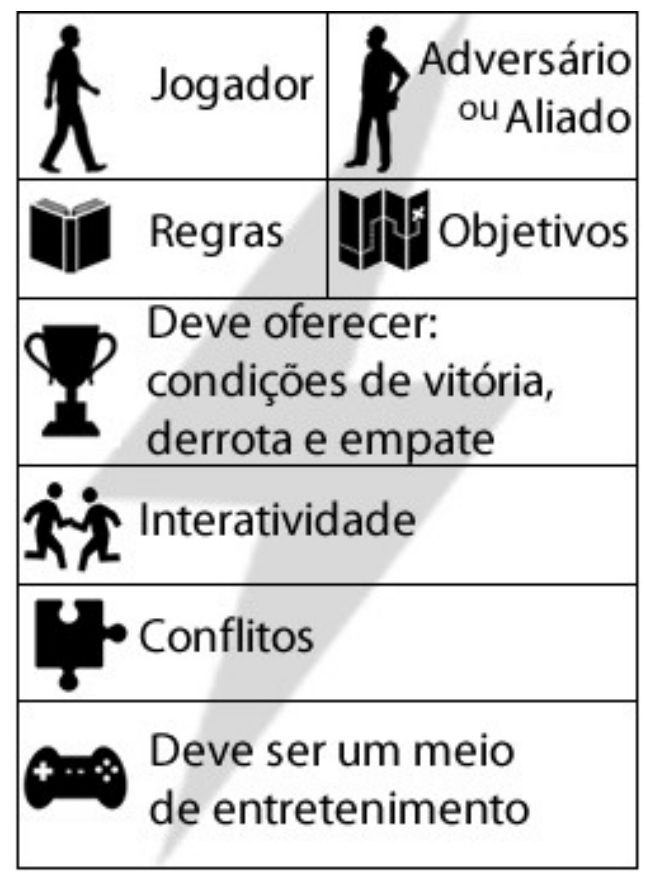

Elaborado pela autora baseado em artigo In Wikipedia

- O jogador, seus adversários ou aliados: são as pessoas envolvidas no jogo em questão. Em se tratando de videogames, adversários e aliados podem ser NPCs. ${ }^{4}$

- Regras: As diretrizes que conduzirão o jogador através do jogo.

- Objetivos: As finalidades que se deseja alcançar no jogo.

\footnotetext{
${ }^{4}$ NPC: Non-player character. Personagens criados pelos desenvolvedores para auxiliar ou antagonizar o jogador em um jogo.
} 
- Condições de vitória, derrota ou empate: O jogo só é finalizado quando algum dos três itens for alcançado. Em casos de jogos $M M O R P G^{5}$, onde as histórias não acabam nunca, este conceito é aplicado nas batalhas, aventuras pelas quais o jogador passa.

- Interatividade: Influência mútua entre os jogadores e $N P C$ s que pode acarretar em estímulo entre os participantes.

- Conflitos: Para ser interessante aos jogadores, o jogo precisa apresentar algum tipo de desafio a ser transposto.

- Entretenimento: O propósito mais básico de um jogo é de divertir quem está envolvido com ele.

\section{$2.1 \mathrm{O}$ jogo na perspectiva de alguns autores}

\section{O jogo da perspectiva de Lev Vygotsky}

Segundo Vygotsky $(1982,1987,1988)$ apud (Kishimoto, 1997) “os processos psicológicos são construídos a partir de junções do contexto sócio-cultural”, de acordo com o autor,o jogo durante a infância é produto de processos histórico-sociais que interferem na maneira como o ser humano pensa.

O conceito que norteia a teoria de Vygotsky (1999) apud (Pimenta, 2011)é o de zona de desenvolvimento proximal, "que ele define como a diferença entre o desenvolvimento atual da criança e o nível que atinge quando resolve problemas com auxílio", ou seja, quando amparadas, as crianças conseguem atingir objetivos mais difíceis do que conseguiriam alcançar sozinhas.

\section{O jogo da perspectiva de Tizuko Kishimoto}

Tizuko Kishimoto, mestre professor da USP/SP, sustenta o pensamento de Vygotsky de que "toda a conduta do ser humano, incluindo suas brincadeiras, é construída como resultado de processos sociais".

Kishimoto (1997) estabelece que usar o jogo na educação "significa transportar para o campo do ensino-aprendizagem condições para maximizar a construção do conhecimento, introduzindo as propriedades do lúdico, do prazer, da capacidade de iniciação e ação ativa e motivadora".

\footnotetext{
${ }^{5}$ MMORPG: Massively Multiplayer Online Role-Playing Game: Jogos baseados em histórias nos quais os jogadores incorporam personagens em um mundo virtual de fantasia no qual interagem com um número abundante de jogadores. In dictionary.com (tradução nossa)
} 


\section{O jogo da perspectiva de Flora Alves}

Flora Alves, mestre em cursos de MBA e palestrante internacional, define o jogo como:

[...] uma atividade voluntária que fazemos porque queremos, espontaneamente. Se tivermos que jogar porque alguém nos ordenou, deixa de ser um game. Ele também não é algo essencial, pode ser considerado algo supérfluo e só se torna urgente se o prazer que se sente com a atividade o transforma em uma necessidade. (ALVES, Flora, 2015, p. 18)

Alves (2015) salienta que jogos são desenvolvidos para que saibamos nos certificar quando alcançamos a vitória. Jogos bem projetados fazem com que o jogador tenha ciência de quando venceu ou perdeu e de que maneira se mede o avanço no mesmo. Em um jogo de damas, a vitória se dá quando um dos jogadores captura todas peças do adversário, o imobiliza ou o deixa com, no máximo, uma peça contra uma Dama. Já nos jogos da saga Mario Bros. ${ }^{\text {TM }}$ a cada fim de fase é necessário alcançar o mastro com a bandeira para poder seguir para próxima área.

Figura 2 - Super Mario Bros. ${ }^{\text {TM }}$ (1985)

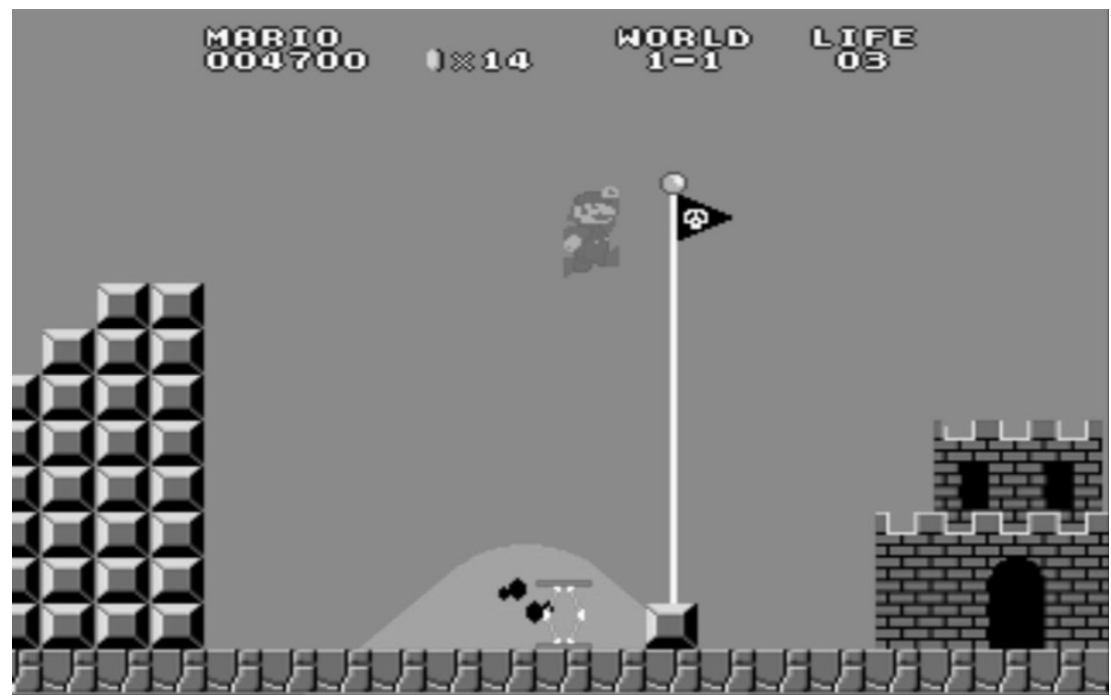

Elaborado por Nintendo Co., Ltd.

\subsection{A origem dos videogames}

Um video game é uma batalha competitiva, uma simulação, realizada através de um jogo eletrônico. Quem joga se coloca diante de um transmissor de imagens: uma TV, smartphone, tela de portátil ou monitor de computador. Geralmente, o termo videogame 
compreende igualmente o suporte no qual os jogos são processados, também nomeado console $^{6}$.

Quando os videogames ainda davam seus primeiros passos, surgiu Pong. Lançado em 1972, em preto e branco, como uma espécie de tênis de mesa no qual dois jogadores, ou um jogador contra o próprio jogo, tinham como objetivo lançar um quadrado de pixels - representando uma bola - para o outro lado da "mesa" e conseguir marcar pontos quando o oponente falhasse em pará-la a tempo. Como mostra essa representação da Figura 3:

Figura 3 - Representação de Pong (1972)
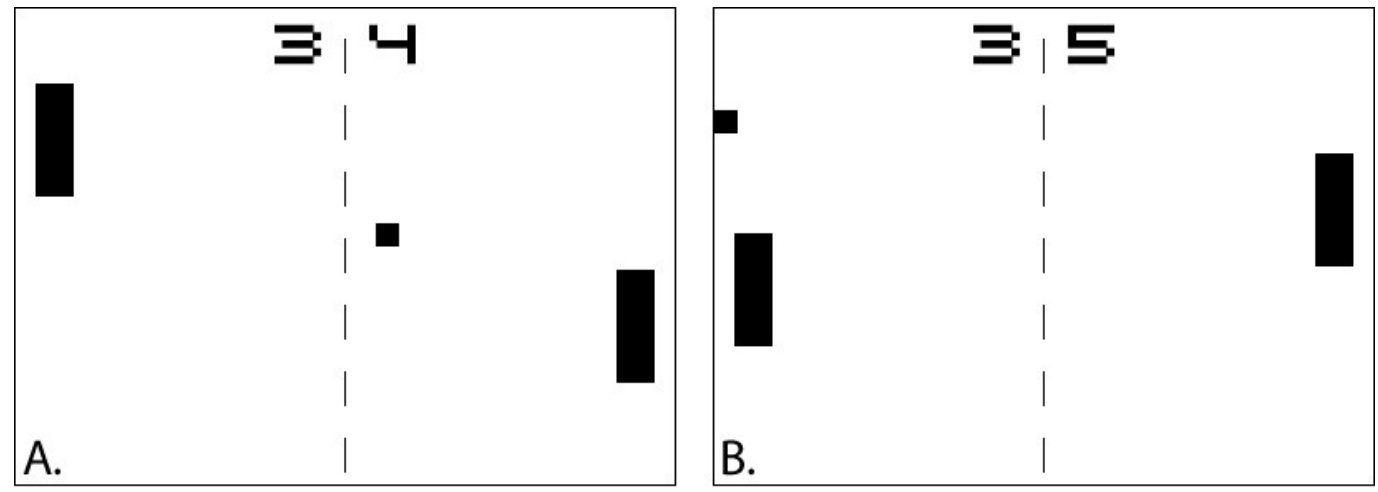

Elaborado pela autora

Pong se tornou um sucesso rápido. Apesar da simplicidade de seus gráficos e sem muita complexidade ou sofisticação no que tange jogabilidade, ele é fundamental na história do videogame. Por ter sido o primeiro videogame lucrativo do mundo, graças a ele um novo setor da indústria foi aberto. Indústria essa que hoje emprega milhões de pessoas e lucra milhões de dólares anualmente.

A cada ano, os videogames se tornam mais presentes nas casas ao redor do mundo e democratizam pouco a pouco sua existência. Neste artigo publicado na Folha de S. Paulo, Chico Felitti (2009) convida para uma exposição de arte contemporânea cujo tema são videogames:

Caso seus pais nunca tenham entendido que jogar videogame é uma arte que exige a sensibilidade de um Monet e a ousadia de um Picasso, leve-os à GamePlay, exposição que pendurou TVs de plasma com 11 jogos na parede e os chamou de obra de arte. (FELITTI, 2009)

\footnotetext{
${ }^{6}$ Alguns exemplos de consoles da atualidade são o Nintendo Switch, o Playstation 4, o XBOX ONE e o Nintendo 3DS.
} 
James Paul Gee ${ }^{7}$ (2004) apud Mattar $^{8}$ (2010), referência quando se pensa no uso de games no aprendizado, propõe uma categorização de jogos digitais por gênero com vários exemplos, sendo alguns:

- Simulations - Simulações (The Sims, SimCity)

- Shooters - Tiro em primeira pessoa (Doom, Call of Duty)

- Adventure games - Jogos de aventura (The Last of Us, The Longest Journey)

- Role-playing games - Jogos onde se representa papéis: (The Elder Scrolls: Skyrym, The Witcher III).

- Arcade games - Jogos de Fliperama (Cadillacs and Dinosaurs, Sonic Adventure 2 Battle).

- Real-time strategy games - Jogos de estratégia em tempo real (Age of Empires, Rise of Nations).

Para Gee (2004) "bons videogames incorporam bons princípios de aprendizagem, princípios estes embasados pelo atual estudo da ciência cognitiva".

Quanto a enorme gama de possibilidades de aprendizado que os videogames podem promover, Mattar (2010) afirma que:

Muitos games são desenhados com a determinação de alguns objetivos para os jogadores, mas os deixam livres para atingir esses objetivos da maneira que preferirem. Mas games poderiam ainda permitir que os jogadores tracem seus próprios objetivos. (MATTAR, 2010, p. 19)

Para muitos jogadores, esse forma de entretenimento é deveras relevante e possui o mesmo peso que o cinema, o teatro. Seu grande diferencial está no fato de que em um videogame o jogador não é um expectador, mas um agente que participa diretamente da execução das ações e do desenrolar da história. Sendo assim, Sebastian Deterding ${ }^{9}$ (2012) afirma: "Jogos eletrônicos incitam centenas de milhares de pessoas ao redor do globo a passar intermináveis horas e dólares muitas vezes desempenhando tarefas básicas - certamente, deve

\footnotetext{
${ }^{7}$ Bacharel em Filosofia pela University of California, em Santa Barbara. Membro da National Academy of Education e $\mathrm{PhD}$ em Linguística pela Stanford University.

${ }^{8}$ Bacharel em Filosofia (PUC-SP), Mestre em Educational Technology (Boise State University), Doutorado em Letras (USP) e Pós-Doutorado (Stanford University), onde foi visiting scholar (1998-1999).

${ }^{9}$ Pesquisador, designer e palestrante é o organizador da Gamification Research Network.
} 
haver uma maneira de usar esse poder para outros propósitos.” (DETERDING, 2012, p. 14, tradução nossa). 


\section{O QUE É GAMIFICAÇÃO?}

De acordo com Mattar (2010) "Muitos jogos são desenhados com a determinação de alguns objetivos para os jogadores, mas os deixam livres para atingir esses objetivos da maneira que preferirem. Mas games podem ainda permitir que os jogadores tracem seus próprios objetivos".Gamificar dinamiza relação professor-aluno e a maneira como o conteúdo didático pode ser apresentado. Ao gamificar, utilizamos recursos dos videogames para estimular um processo de aprendizagem interessante e correspondente às expectativas dos alunos que já nasceram na era digital.

Figura 4 - Elementos da Gamificação

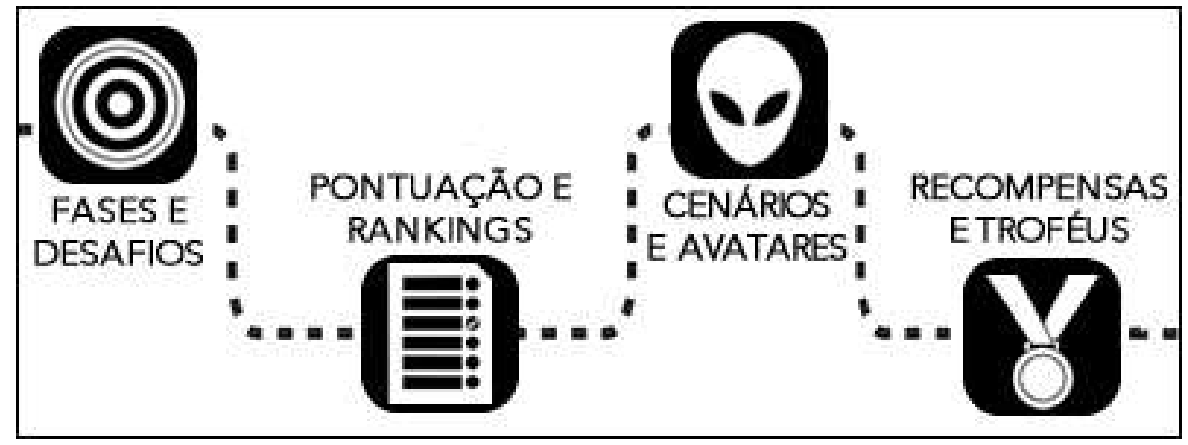

Elaborado pela autora baseado em infográfico de Marcela Lorenzoni In Geekie

A gamificação lança mão de mecanismos como a •linguagem tecnológica: Por viverem conectados, os alunos estão familiarizados com as ferramentas que podem ser utilizadas no ambiente de aprendizagem gamificado, como celulares, computadores e tablets; •resolução de problemas: Com os recursos disponibilizados pelo professor, alunos usam a criatividade para resolver os problemas apresentados; •interatividade: Ao invés de somente serem agentes passivos na aula, os alunos tomam decisões e interagem com diferentes cenários propostos; -alcance de objetivos: Tudo que aprendem serve a um propósito - seja ele passar para o próximo nível ou ganhar recompensas; •trabalho em equipe: Os alunos pensam juntos em soluções para os problemas expostos.

Se é tão interessante assim, porque não estamos investindo nisso? Na década passada, a dificuldade na implementação da gamificação foi de que, como atesta Squire ${ }^{10}$ (2004): "[...]

\footnotetext{
${ }^{10}$ Professor na University of California, Irvine, famoso pela pesquisa em design de jogos para a educação.
} 
existem poucos modelos de como usar jogos contemporâneos em ambientes formais de aprendizagem.” (SQUIRE, 2004, p. 438, tradução nossa).

Atualmente, as opções de modelos já são plurais e já abarcam infinitas possibilidades de uso, mas as barreiras a serem, ainda, transpostas envolvem a aceitação na mudança do paradigma do aluno em sala, em como o professor precisará mudar drasticamente a maneira como conduz sua aula, possivelmente precisando aprender sobre um novo modelo de metodologia e ainda o investimento das escolas - nas ferramentas necessárias - para incluir a gamificação no ambiente de aprendizado. 


\section{MOTIVAÇÃO}

A motivação, em linhas gerais, tem a ver com as causas que levam um indivíduo a executar determinada ação. Motivação tem a ver com a busca de satisfação e prazer. No entanto existem situações nas quais decidimos fazer algo, simplesmente por sermos orientados ou pela promessa de uma recompensa. De acordo com Alves:

[...] Motivação é um assunto complexo, pois não somos motivados pelas mesmas coisas. Muitas vezes não temos consciência das razões pelas quais fazemos algumas coisas, pois estas podem ser complicadas e não diretamente relacionadas com as nossas experiências. (ALVES, Flora, 2015, p. 56)

Na relação aluno-professor, a gamificação pode ser uma união entre útil e agradável: útil para o professor abordar a matéria e agradável para os alunos, pois o conceito de jogos lhes é familiar.Em se tratando de gamificação, a motivação exerce um papel fundamental para o alcance do sucesso, pois alunos motivados aprendem. Como meio de entretenimento, os videogames tem muitos adeptos:

[...] As pessoas jogam, envolvem-se e dedicam seu tempo a esta atividade em busca de emoções positivas e diversão, desta forma a motivação é um ponto de extrema importância quando o assunto é Gamification e aprendizagem. (ALVES, Flora, 2015, p. 56)

Entender a importância da motivação intrínseca e extrínseca e a relação entre elas é de suma importância na hora de desenvolver soluções de aprendizagem gamificadas. A motivação intrínseca é a força que vem de dentro, é o interesse natural que sentimos em fazer determinada atividade. Flora Alves (2015) a classifica como "algo que acontece quando você se diverte tanto no percurso de uma viagem quanto ao chegar a seu destino". Já a motivação extrínseca, Flora Alves explica como sendo "fruto do ambiente externo [...] acontece para que o indivíduo obtenha alguma recompensa ou evite uma determinada punição." Ela evoluirá conforme o indivíduo interage com o meio no qual está inserido. Quando apresentado ao conteúdo de maneira divertida, a motivação extrínseca tende a aflorar nos alunos.

John Keller, professor emérito da Florida State University, elaborou um modelo para melhorar o apelo motivacional de material didático para designers aprendizes. O modelo de Keller possui quatro fatores que são: Atenção, Relevância, Confiança e Satisfação que formam o acrônimo ARCS. De acordo com Keller estes quatro itens são necessários para estimular e manter a motivação dos alunos. Abaixo, a Figura 5 apresenta um resumo dos fatores supracitados: 
FIGURA 5 - Modelo de Keller

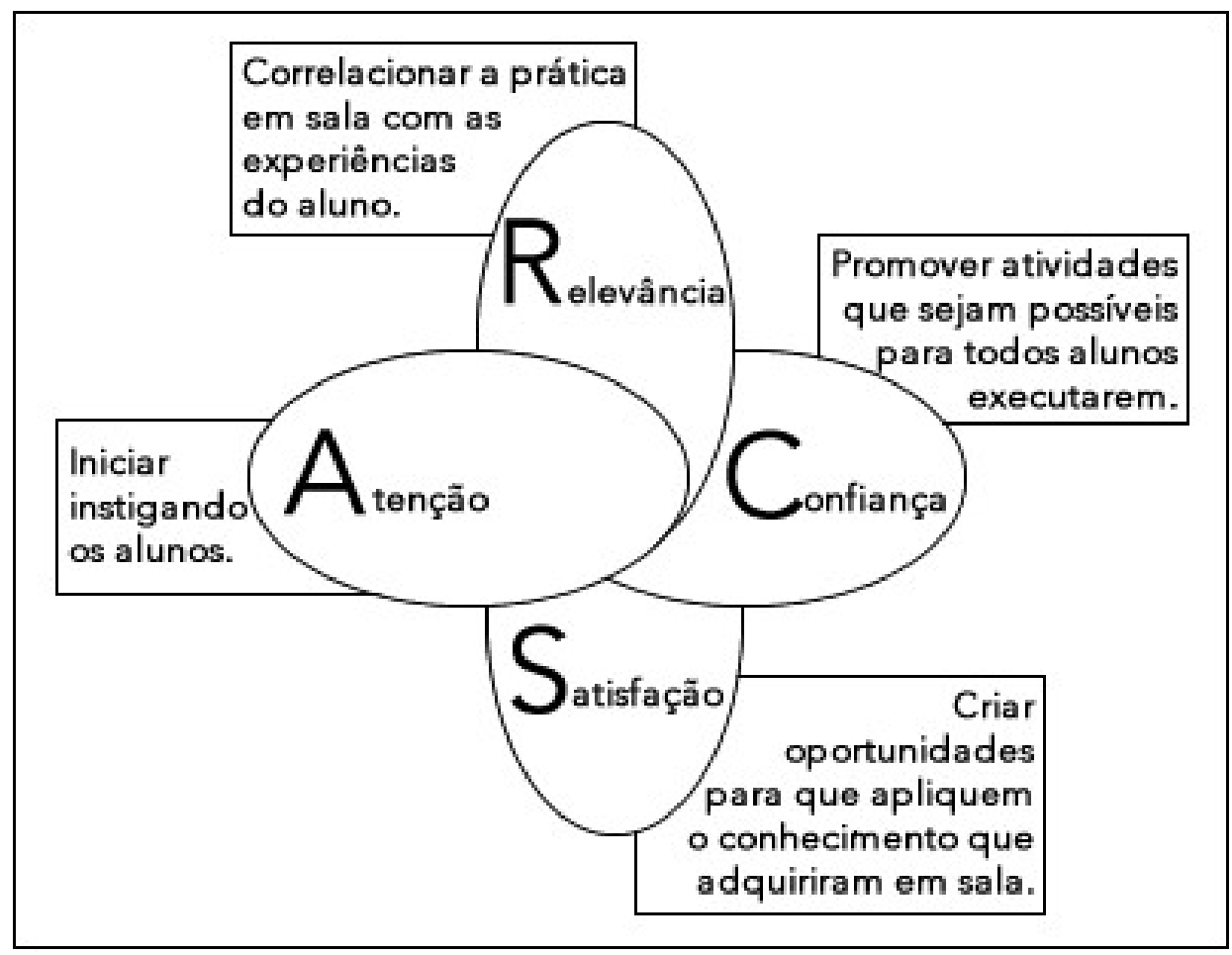

Elaborado pela autora segundo Keller (1987, p. 3-6)

Em detalhes:

- Atenção: Usar recursos como surpresa e incerteza para instigá-los. Estimular a curiosidade ao propor desafios, perguntas ou problemas.

- Relevância: Usar exemplos com os quais os alunos possam se identificar. Apresentar os objetivos e propósitos de cada atividade proposta, definindo os objetivos e finalidades das tarefas ou mesmo permitir que os alunos definam quais metas desejam atingir.

- Confiança: Fornecer níveis de dificuldade variados que concedam a todos possibilidade de sucesso e que permitam a todos alcançar seus objetivos pessoais. Dar feedback para que os alunos tenham consciência do que aprenderam e/ou das novas habilidades adquiridas.

- Satisfação: Utilizar o conhecimento adquirido na atividade proposta em uma situação real ou mesmo simulada. Lançar mão novamente do feedback para que os alunos mantenham o comportamento desejado e sigam sentindo-se estimulados.

O modelo de Keller pode perfeitamente ser aplicado a Gamificação devido a sua natureza voltada para a promoção e manutenção da motivação. Algo que todo professor deve fomentar. Com alunos motivados, o ambiente de aprendizado tende a ser um lugar formidável onde os alunos se sentem felizes de estar. 


\section{ENGAJAMENTO}

Analisando a etimologia da palavra, o termo engajar é originário do francês engager, cujo significado é “dar como caução", “empenhar” ou "dar em garantia”. Na língua portuguesa e na inglesa seu significado tem a ver com participar de modo voluntário para algum trabalho ou atividade.

Em artigo publicado em Harvard Business Review, Karin Parodi ${ }^{11}$ comenta:

Engajar é um dos grandes desafios das organizações no que se refere à gestão de pessoas e à obtenção de resultados superiores. Existe um mundo novo, trazendo obstáculos também nunca vistos. Uma rotina exaustiva, formada por novas tendências, cenários em transformação constante, novas demandas chegando a uma velocidade jamais vista. Toda essa complexidade faz parte do dia a dia das organizações e das pessoas. (PARODI, Karin, 2015)

É uma grande conquista do professor impulsionar o envolvimento e a interação entre alunos e conteúdos propostos e assuntos abordados no ambiente de aprendizado. E de forma alguma devemos criar barreiras para os vários tipos de meios que existem para obter tal feito. Squire (2004) afirma que:

[...] Enquanto muitos tentam jogar uma mídia contra a outra na concepção dos ambientes de aprendizado, este trabalho mostra que o real valor está em encontrar maneiras de sobrepô-las e interligá-las, procurando formas de engajar os alunos em experiências de jogo de tal forma que eles queiram e precisem buscar informações em textos para resolução de problemas. (SQUIRE, p. 336, tradução nossa)

Squire (2004) salienta que "Jogos digitais são uma forma, emergente, de entretenimento que está sendo analisada como ferramenta de engajamento de alunos por um número cada vez maior de educadores." (SQUIRE, 2004, p. 438, tradução nossa).

De acordo com Richard Allan Bartle ${ }^{\mathbf{1 2}}$ existem quatro tipos de jogador: predadores, conquistadores, exploradores e comunicadores. A seguir, o modelo de Bartle na Figura 6:

\footnotetext{
${ }^{11}$ CEO da Career Center: Fundada em 2001 com o propósito de oferecer assessoria em Outplacement para executivos.

${ }^{12}$ Escritor britânico, professor e pesquisador de games. Pioneiro na indústria de MMORPGs.
} 
FIGURA 6 - Tipos de jogadores

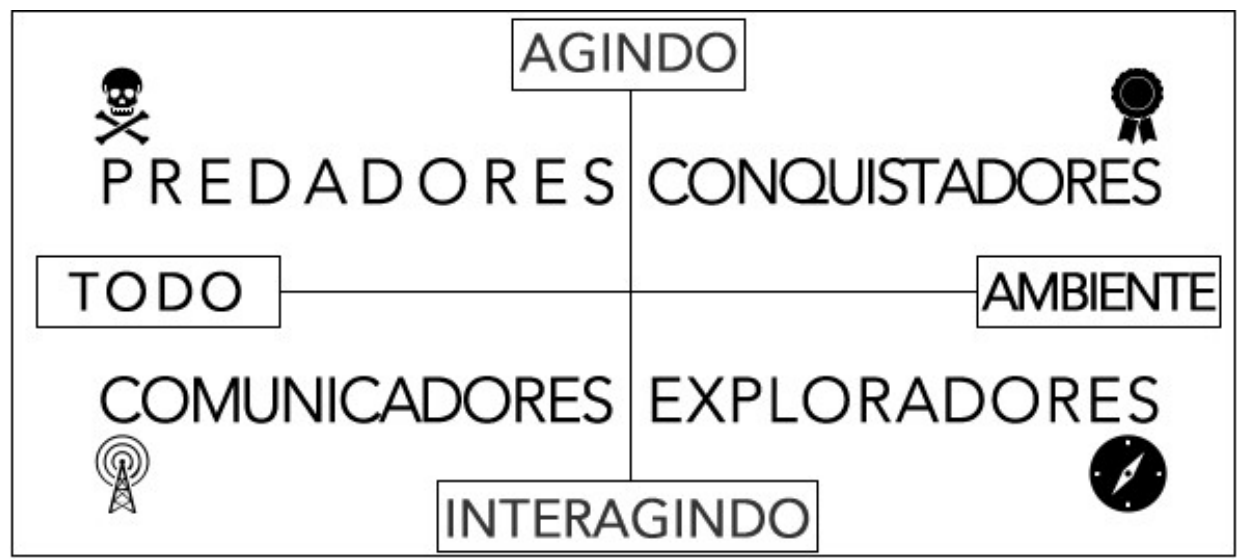

Elaborado pela autora segundo Bartle apud (Alves, 2015, p. 82)

- Os predadores têm por objetivo vencer seus adversários. Tendem a assumir posição de liderança para garantir que sairão vitoriosos das batalhas.

- Os conquistadores se focam em conseguir recompensas: Seja passar de fase, obter trophies/achievements/accomplishments ${ }^{13}$ ou mesmo terminar um jogo com $100 \%$ de aproveitamento.

- Os exploradores querem entender os porquês, os motivos. Se diferem dos conquistadores por estarem mais interessados em aproveitar o percurso, no desenrolar da história do que no status provindo do triunfo.

- Os comunicadores se interessam mais por relacionarem-se com os outros jogadores. Notadamente, são o tipo mais comum de jogador, dada a natureza social do ser humano.

Amy Jo $\mathrm{Kim}^{14}$ diz que "você deve pensar no público que deseja engajar e pensar no comportamento desse público numa dada situação." e ressalta ainda que se "quer engajar, por exemplo, jovens mães é possível que [...] você tenha mais chance de engajamento por meio de uma atividade colaborativa". (KIM apud ALVES, Flora, 2015, p. 85).

Na Figura 7, abaixo, temos segundo Karl M. Kapp, os pensamentos de cada tipo de jogador:

\footnotetext{
${ }^{13}$ Sistemas de recompensas dos consoles Playstation/Xbox/Wii U respectivamente.

${ }^{14}$ Nomeada pela Fortune como uma das 10 mulheres mais influentes no mundo dos games.
} 
FIGURA 7 - Pensamentos de cada tipo de jogador

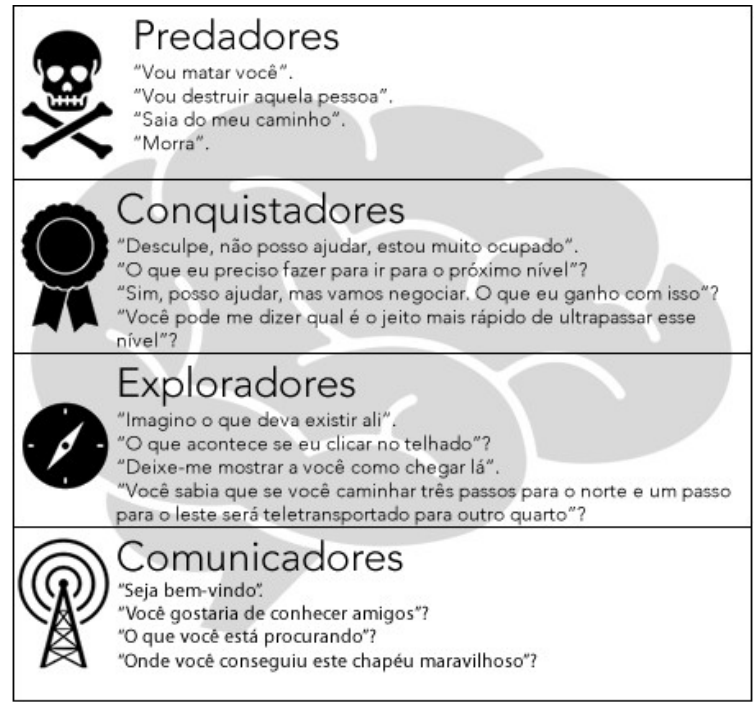

Elaborado pela autora segundo Kapp apud (Alves, 2015, p.82-85)

Sendo assim, para entender melhor como engajar os diferentes tipos de alunos/jogadores, Kim propõe uma adaptação do modelo de Bartle, na Figura 8, a seguir, utilizando verbos de engajamento, para ajudar a identificar o tipo de ação que o professor pretende promover: 
FIGURA 8 - Verbos de engajamento social e ação

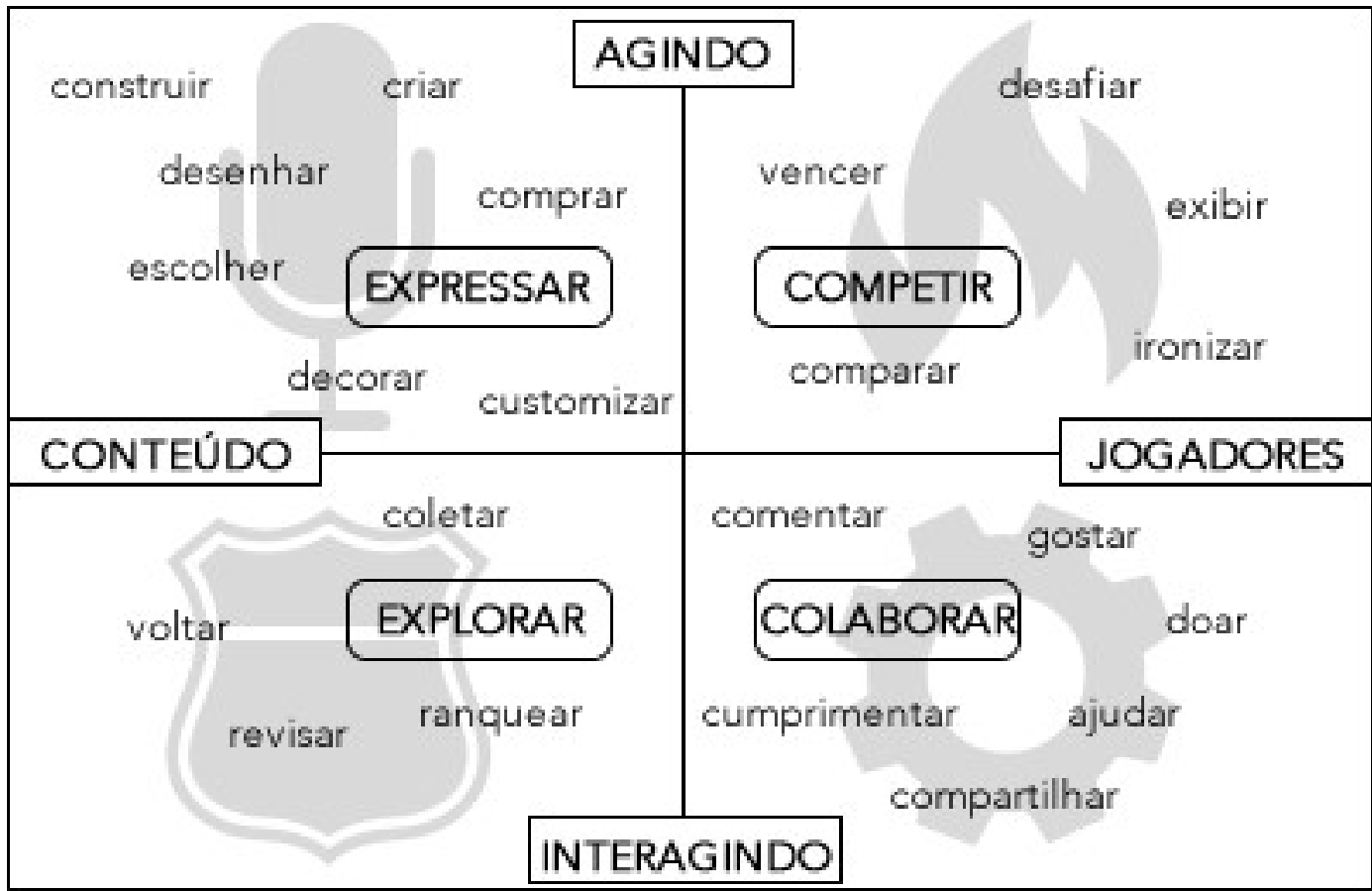

Elaborado pela autora segundo Kim apud (Alves 2015, p. 86)

Com os verbos acima em mente, as atividades podem ser criadas envolvendo, mesmo que cada um por vez, todos os quatro tipos de alunos/jogadores. 


\section{NATIVOS DIGITAIS}

As pessoas que nasceram após meados da década de 80 são os chamados nativos digitais. Suas vidas, desde tenra idade estiveram em contato com recursos e avanços tecnológicos como a televisão, computadores, videogames e, recentemente, smartphones.

As pessoas, a cada dia, vêm alterando diversos hábitos, como consultar um médico, fazer compras, se divertir, namorar, ou aprender. Tais avanços tecnológicos transformam, cada vez mais, o dia a dia das crianças e dos adolescentes. Eles desenvolvem uma importante capacidade de se relacionar intimamente com mídias digitais e com o ritmo veloz das informações. (CARIBÉ, Andersen et al. apud ALVES; NERY, 2015, p. 139).

A viabilização e democratização do acesso aos mecanismos de informação modificaram o comportamento dos indivíduos supracitados, eles executam muitas atividades simultâneas, são ansiosos por informação e têm dificuldade de se concentrar em uma única ação, devido a sua natureza multitarefa.

\footnotetext{
Assistimos participativamente a emergência de uma nova forma de cultura que tem nos solicitado a estabelecer relações cada vez mais íntimas com os meios digitais, sobretudo a internet. Os novos códigos e símbolos que regem tais relações se hibridizam no intuito de fazer transmitir e circular mensagens, reorganizando as estruturas de comunicação de "tempos atrás". (SOUZA, Ivana Carolina apud ALVES; NERY, 2015 p. 79).
}

Como indivíduos das Gerações $\mathrm{Y}$ e $\mathrm{Z}$ já nascem nesse mundo, três ponto zero, no qual as tecnologias estão intimamente ligadas a grande parte do que fazemos, eles já são naturalmente estimulados a desenvolverem sua engenhosidade e capacidade inventiva, o que "seria suficiente para tornar esses indivíduos mais inteligentes e criativos" (CARIBÉ, Andersen et al. apud ALVES; NERY, 2015, p. 140).

Na Figura 9, a seguir, em números, é possível notar como os nativos digitais estão desenvolvendo suas habilidades com o computador muito antes de certas competências da vida prática: 
Figura 9 - Desenvolvimento dos Nativos Digitais

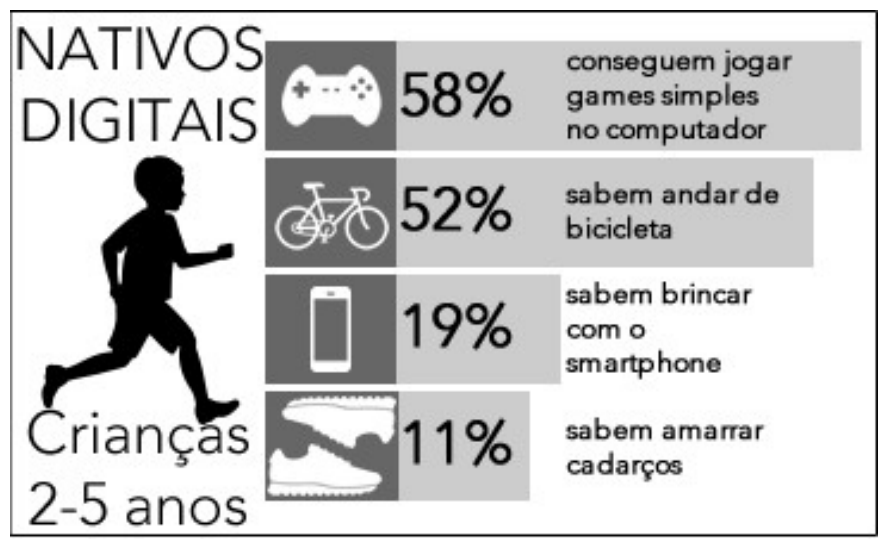

Elaborado pela autora baseado em pesquisa feita há 7 anosIn AVG Digital Diaries.

Como a tecnologia é tão cotidiana, os alunos tiram muitas vantagens de, no ambiente de aprendizado, fazer paralelos entre seu conhecimento de mundo e o conteúdo que aprendem, Caribé afirma:

Um exemplo disso está na interação dos jovens com os videogames. Os autores da visão "apocalíptica" costumam ver essa interação como algo perigoso, já que esses dispositivos, de alguma forma, estariam provocando, por repetição, comportamentos agressivos nos usuários. Os games também são acusados de prejudicar o desempenho escolar desses jovens e de, em alguns casos, torná-los viciados. Por outro lado, diversos autores, a exemplo de Johnson (2012), Gee (2004), Moita (2007) e Alves e Hetkowski (2012), afirmam que os games podem ser benéficos àqueles que jogam com certa frequência. Para esses autores através do jogo a criança internaliza regras e encontra soluções para conflitos que lhe são impostos na vida real. Ela tende a imitar a realidade no seu faz-de-conta, atuando por simulação em um nível superior ao que se encontra.

(CARIBÉ, Andersen et al. apud ALVES; NERY, 2015, p. 141).

Esta nova perspectiva desencadeia novos desafios para a educação que invariavelmente é bem sucedida ao aproximar o aprendizado à realidade do aluno. Levando em conta a análise do que se precisa mudar para melhorar e como isso será feito, em se tratando de aprendizagem o "sucesso depende de um bom diagnóstico e definição de objetivos." (ALVES, Flora, 2015, p. 153).

Na Figura 10, abaixo, vemos um paralelo entre alguns aparelhos familiares aos imigrantes digitais e o aparelho familiar aos nativos digitais. $\mathrm{O}$ smartphone, convenientemente, integra todos os itens da esquerda em um único aparelho. 
Figura 10 - Equipamentos familiares

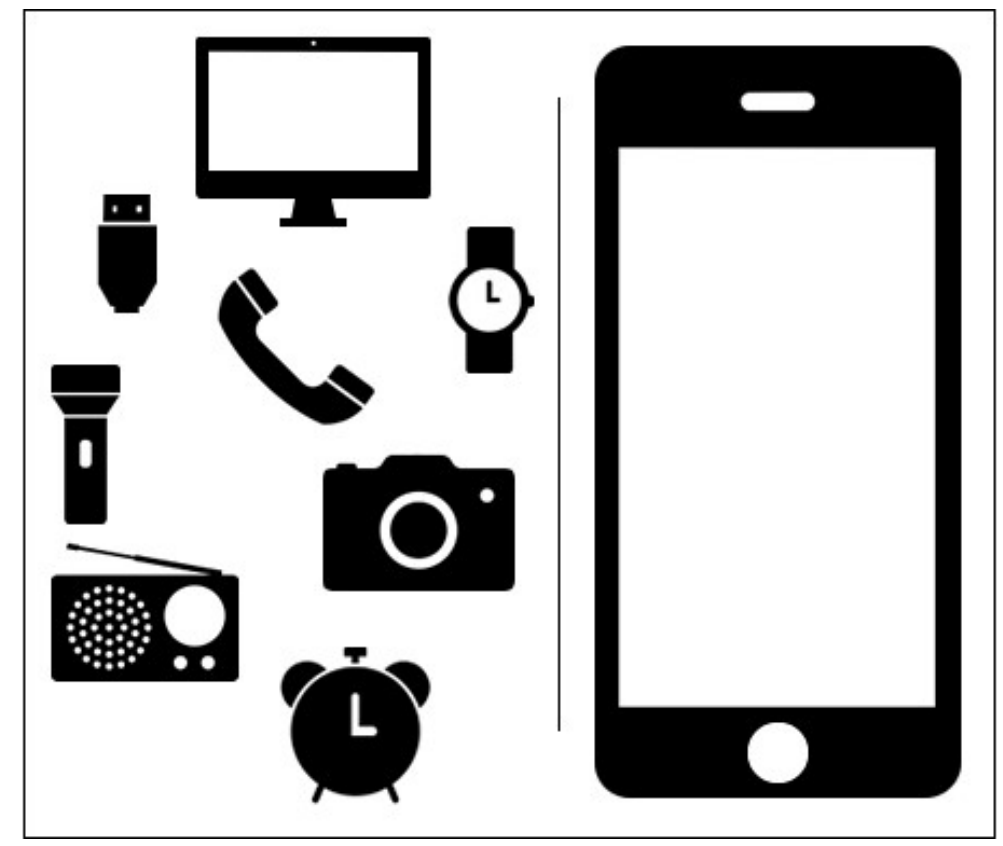

Elaborado pela autora.

\subsection{Ambiente de aprendizagem escolar}

De acordo com a definição do dicionário Priberam: ambiente, do latim ambiens, entis, é o que é relativo ao meio físico ou social; conjunto das circunstâncias culturais, econômicas, morais e sociais em que vive um indivíduo; espaço físico delimitado.

Ao delinear o ambiente de aprendizagem escolar, temos segundo Moreira (2007):

Um lugar previamente organizado para promover oportunidades de aprendizagem e que se constitui de forma única na medida em que é socialmente construído por alunos e professores a partir das interacções [sic] que estabelecem entre si e com as demais fontes materiais e simbólicas do ambiente (MOREIRA, 2007, p. 56).

O ambiente de aprendizagem escolar deve ser um espaço onde o aluno está exposto a uma sequência de acontecimentos que promovem a aprendizagem.

Inserido no ambiente de aprendizagem escolar, está o professor mediando as práticas educativas e se envolvendo diretamente com o aprendizado ao preparar, organizar e sistematizar a aprendizagem. O professor também é o responsável por direcionar e orientar os alunos durante o processo de aquisição do conhecimento. Quanto mais cativante e agradável for o ambiente de aprendizagem escolar, maior a chance de êxito na aprendizagem. 
Nós educadores sabemos que é preciso oportunizar um ambiente democrático e propício ao desenvolvimento harmonioso dos alunos, objectivando [sic] a participação e a responsabilidade de cada um nesse ambiente, pois quando o mesmo é agradável, a aprendizagem ocorre com mais facilidade e torna-se prazerosa. (ANTUNES, 2003, p. 25).

Mesmo as condições físicas sendo favoráveis - como se dispõe as carteiras, a posição dos alunos - a figura do professor ainda é o maior motivador para obtenção de êxito e alcance de resultados satisfatórios.Ele ajuda na formação de indivíduos questionadores que desenvolvem suas habilidades de argumentação e são capacitados a opinar sobre diversos assuntos. É importante que atue, de forma imparcial, fomentando debates produtivos levando em consideração o respeito entre todos. Assim estimulando a curiosidade dos alunos para que busquem, pesquisem e aprendam sobre as mais diversas áreas e assuntos.

\subsection{Dinâmica de sala de aula tradicional}

Apesar do mundo ter mudado tanto ao longo dos últimos anos - com o avanço veloz da tecnologia - e de nós estarmos cada vez mais conectados, de nossas vidas estarem cada vez mais entrelaçadas com as informações contidas em um smartphone e na web, a escola no Brasil - em se tratando de estar congruente à realidade fora de sala - caminha a passos de formiga rumo a modernidade. Como pontua Mattar (2010):

[...] a educação dos nossos jovens está hoje brutalmente segmentada: na escola, o ensino de um conteúdo descontextualizado que o aluno tem de decorar, passiva e individualmente; nos games, o aprendizado em simulações que o próprio jogador ajuda a construir, ativa e colaborativamente. (MATTAR, 2010, p. xiii)

Em linhas gerais, ainda seguimos um modelo tradicional de ensino: Professor que "fala e expõe", dando a aula de pé, a matéria sendo apresentada através de um quadro branco, alunos sentados organizadamente em carteiras enfileiradas.

Aprisionados a um modelo engessado, os alunos têm dificuldade de associar modernidade e escola, aprendizado e dinâmica. E sentem que a aula é enfadonha. Afinal, quando comparado com suas vidas, o ambiente de aprendizado - nos moldes atuais - é um ambiente de monotonia onde o professor fala e os alunos escutam, mas não ouvem, pois estão com os olhos e atenção voltados para as telas dos seus smartphones fazendo qualquer coisa que eles consideram mais interessante. 


\title{
6.3 Dinâmica de sala de aula para nativos digitais
}

Os alunos das gerações $\mathrm{Y}$ e $\mathrm{Z}$ - nativos digitais - são multitarefas, procuram a internet antes de qualquer outro meio para obter conhecimento e olham para a tecnologia como algo conveniente, natural e positivo, assim como os professores que também são nativos digitais. Por outro lado, professores mais experientes - imigrantes digitais - que viveram a migração e a revolução que a tecnologia desencadeou: "[...] assumem que os educandos são os mesmos que sempre foram, e que os mesmos métodos que funcionaram com os professores quando eram estudantes irão funcionar com seus alunos agora". (PRENSKY, 2010, p. 3).

Estes professores ainda não se adequaram à presença da tecnologia em sala de aula muitas vezes a demonizam - e têm dificuldade de relacionar seu uso com o aprendizado.

A escola foi projetada para um paradigma de aluno que já não condiz com o atual, segundo Prensky (2010):

\begin{abstract}
Precisamos trabalhar com nossos professores e convencê-los - por mais difícil que isso possa ser em alguns casos - a pararem de palestrar e a começarem a permitir que seus alunos aprendam por si mesmos. Em vez de virem para a aula com planos de aula que digam: "Aqui temos três causas principais de [qualquer coisa]. Por favor, façam suas anotações...!", os professores precisam começar a dizer: "Existem três causas principais para [qualquer coisa]. Vocês têm 15 minutos para usar suas tecnologias e descobrir quais são e, depois, vamos discutir o que vocês encontraram. (PRENSKY, 2010, p. 204).
\end{abstract}

Ficará a cargo dos professores, repaginar o sistema de ensino e se adequar a nova realidade do aluno de hoje. Ele precisa buscar compreender melhor como pensa o aluno moderno e o mundo onde ele está inserido, assim conseguindo instigá-lo, e proporcionar um ambiente de aprendizado condizente com sua vida "lá fora".

Se conseguirmos concordar que o papel da tecnologia nas nossas salas de aula é o de apoiar a nova pedagogia a partir da qual os alunos ensinam a si mesmos com a orientação do professor, então poderemos nos movimentar muito mais rapidamente pela estrada que leva à obtenção dessa meta. (PRENSKY, 2010, p. 204).

Cabe ao professor, mediar, cooperar com o aluno e aproveitar as ferramentas que os recursos tecnológicos podem oferecer ao aprendizado. Promovendo assim, o alcance do potencial máximo de cada aluno. 


\section{DAS IMPLICAÇÕES NA APLICAÇÃO DA GAMIFICAÇÃO}

Ponderando todas as mudanças que a tecnologia provocou na sociedade, a sala de aula tradicional, onde o professor expõe e o aluno assiste passivamente, está fadada a - cada vez mais - se tornar algo muito distante do que os alunos vivem em sua realidade. Mattar (2010) observa que "A geração de gamers já constitui um grupo muito grande, e não estamos prestando a devida atenção à revolução causada por esse fenômeno." (MATTAR, 2010, p. XV). Zanolla aponta:

[...] a depender da didática do professor, a atividade de usar o quadro-negro pode tornar o ensino repetitivo e limitar os alunos a regras fechadas e autoritárias, entretanto, passa-se para outros instrumentos e o risco é o mesmo." (ZANOLLA, 2010 apud ALVES; NERY, 2015, p. 190)

\subsection{Aspectos negativos $x$}

Considerando o lado negativo, a implantação da gamificação pode acarretar consequências indesejáveis, considerando os itens na Figura 11, abaixo:

Figura 11 - Itens a levar em consideração

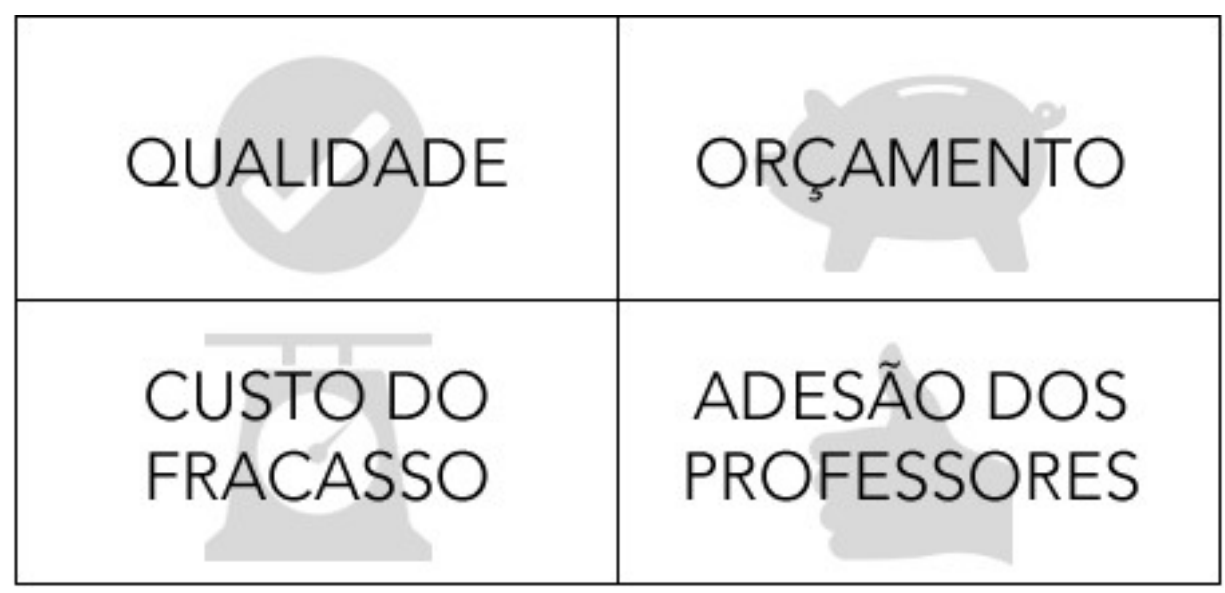

Elaborado pela autora.

No que se refere a qualidade, podemos citar 4 tópicos: > Caso o jogo utilizado pelo professor possua um enredo desinteressante, os alunos não se sentirão engajados pela história. > No quesito jogabilidade, os controles, a maneira como os comandos são dispostos, como botões/teclas são utilizados podem criar empecilhos que façam os alunos acharem que não vale a pena enfrentar a curva de aprendizado. > Gráficos ruins serão uma grande barreira na busca da aceitação. Hoje, gráficos são um aspecto de extrema importância para os jogadores, 
considerando a qualidade gráfica que os videogames já alcançaram. > Missões cujos níveis de dificuldade sejam inadequados poderão: a) ser impossíveis de serem concluídas ou extremamente fáceis, ambos casos desencadeariam o mesmo desfecho: os alunos perderão o interesse e se sentirão desestimulados.

Em se tratando do custo do fracasso: Nos videogames, o peso de fracassar é minimizado, pois pode-se recomeçar do último ponto salvo. O jogador encara o game over como uma oportunidade de aprendizado, ele pode "morrer", mas é só carregar e tentar mais uma vez e, por isso, não tem medo de tentar de novo até alcançar seu objetivo. Em sala de aula, o custo do fracasso é considerado maior devido a exposição do aluno perante os colegas. E o medo de errar em público.

Em relação a orçamento e recursos, Nagata constata que "[...] não adianta introduzir tecnologia sem mudar a metodologia, sem usar todo o seu potencial, sem aproveitar o que cada mídia tem de melhor." (NAGATA, Aline Akemi apud ALVES; NERY. 2015 p. 190). Portanto um investimento em bons equipamentos e capacitação dos professores - para se adequarem as tecnologias que passarão a ser suas ferramentas de trabalho - é imprescindível para obter sucesso na empreitada. O que nos leva ao último tópico.

No que diz respeito a adesão dos professores, o êxito na mudança do paradigma do aluno em sala dependerá em grande parte do engajamento do professor em instruir-se e preparar-se para estar apto a mediar a relação entre seus alunos e os jogos propostos.

\subsection{Aspectos positivos}

Olhando pelo lado positivo, lançar mão da gamificação - introduzindo jogos na sala de aula - pode ajudar a adequar o ambiente de aprendizado à realidade dos nativos digitais. Tal manobra pode desempenhar o papel de tornar a escola um espaço que condiz com as atividades, estilo de vida e aprendizado dessa geração que tem relação tão íntima com informação, criatividade e dinâmica. E ainda, pode conseguir estreitar essa relação entre aluno e professor, que hoje é tão distante.

Ao inserir a multitarefa, comunicação, trabalho em equipe, tomada de decisão, proporcionar aos alunos a experiência prática das ações, o educador poderá engajar o aluno e estimular a obtenção do conhecimento através das práticas familiares que ele já usa no dia a dia. Transformando a sala de aula em uma extensão da realidade que ele já vive, cuja dinâmica ele já está acostumado. Segundo Lynn Alves (2005): 
[...] a aprendizagem que é construída em interações com os games não é mera cópia mecânica das situações vivenciadas, mas uma ressignificação que os jogadores fazem das imagens e ações presentes nos conteúdos dos jogos eletrônicos mediante seus modelos de aprendizagem construídos ao longo de sua estruturação como sujeitos. (ALVES, Lynn, 2005, p. 118-119)

Estreitar a relação entre a sala de aula e o "mundo lá fora" faz total sentido e é exatamente o que devemos buscar, para reacender a chama do interesse do aluno e tornar a motiválos considerando que, como constata Mattar (2010):

[...] se essas crianças e jovens tivessem a oportunidade de aplicar o que são obrigados a estudar. (MATTAR, 2010, p. xiii)

O aprendizado tornará a alcançar seu propósito primordial de formar alunos capacitados, motivados e engajados. Ao invés de memorizar informações para passar nas provas, eles realmente terão a oportunidade de aprender e reter informações referentes a variados assuntos. Na Figura 12, abaixo, um conceito moderno de educação:

Figura 12 - Conceito moderno de educação

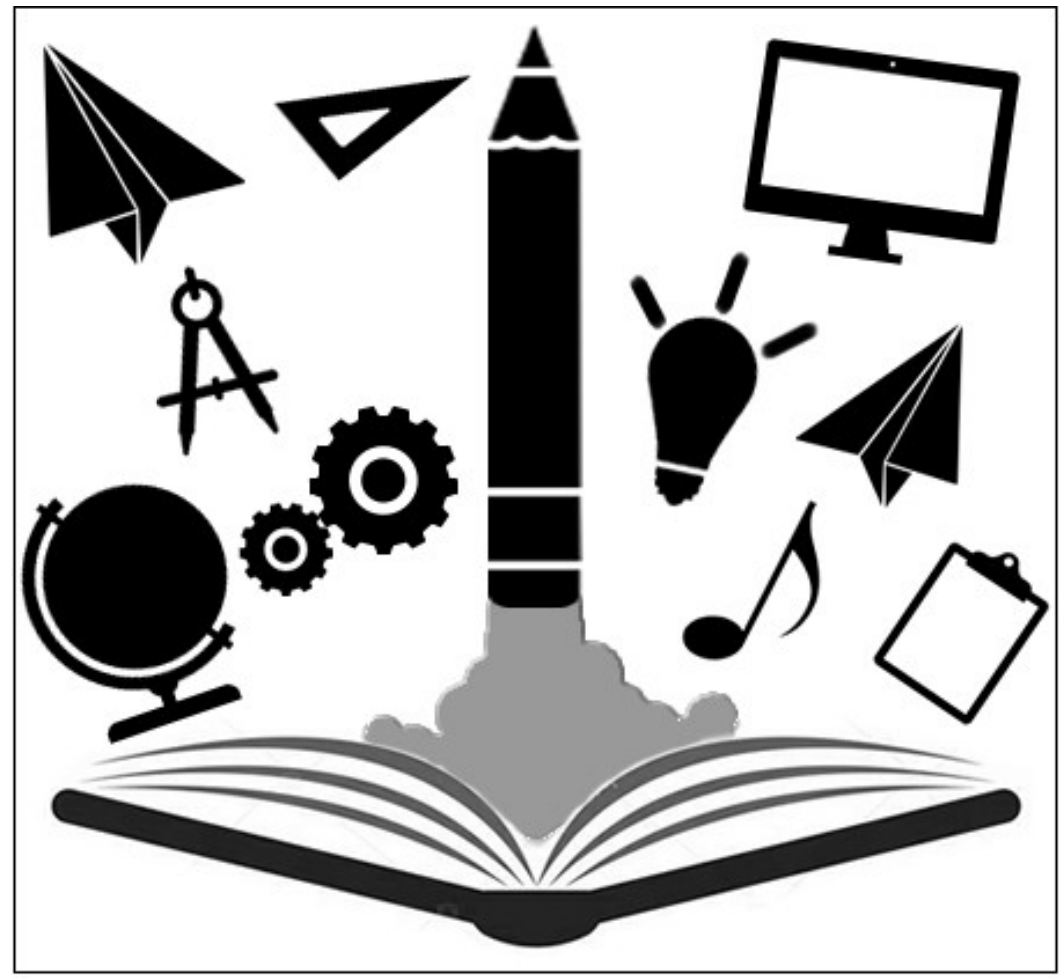

Elaborado pela autora baseado em arte de domínio público In Freepik 


\section{CONCLUSÃO}

A escola no Brasil segue ainda um modelo tradicional de ensino que está desalinhada com os anseios e a "realidade fora de sala" dos alunos nativos digitais, o que, como vimos anteriormente, os leva a não conseguir associar modernidade e escola, e consequentemente: aprendizado e dinâmica.

Vivemos uma crise, um choque de gerações, há um abismo entre professor e aluno. Poderiam os jogos melhorar a forma como se aprende e ensina? Considerando a familiaridade que os nativos digitais têm com a presença da tecnologia, os jogos podem ser um grande trunfo na mudança do paradigma do aluno em sala. O professor é a engrenagem mais importante na adoção dessa mudança, mas há muitos empecilhos nesse caminho de revolução.

É possível e benéfico dinamizar a sala de aula e adequá-la às expectativas destes nativos digitais? Recursos como a gamificação podem ser interessantes e úteis na quebra do paradigma supracitado, não obstante, os questionamentos que surgiram ao longo deste trabalho não se findam com estas conclusões parciais. Portanto, esse trabalho não abrange conclusões definitivas, apesar de identificar pontos a serem estudados e analisados mais a fundo para proporcionar um entendimento maior da adoção da gamificação como facilitador do aprendizado e mecanismo de estreitamento da relação professor-aluno nativo digital. 


\section{REFERÊNCIAS BIBLIOGRÁFICAS}

ALVES, Flora. Gamification. Como criar experiências de aprendizado engajadoras. 2. ed. Local: DVS, 2015, 200p.

ALVES, Lynn. Game over: jogos eletrônicos e violência. São Paulo: Futura, 2005.

ALVES, Lynn; NERY, Jesse (Org.). Jogos eletrônicos, mobilidades e educações. Trilhas em construção. 1. ed. Bahia: Edufba, 2015, 372p.

ANTUNES, Celso. Relações interpessoais e auto-estima: a sala de aula como um espaço do crescimento integral. Rio de Janeiro: Fascículo 16. Vozes, 2003, 72p.

BARCELLOS, Helter Jeronymo L. Durante Palestra no ISAT em 24 out. 2013.

DETERDING, Sebastian. Gamification: designing for motivation. Interactions. v. 19, n. 4, p. 14-17, 2012. Disponível em:

$<$ https://www.researchgate.net/profile/Sebastian_Deterding/publication/244486331_Gamifica tion_Designing_for_motivation/links/0a85e53a049814673c000000.pdf $>$. Acesso em: 15 mar. 2018 .

FELITTI, Chico. Aperte "Starte". Folha de S. Paulo, São Paulo, 6 jul. 2009. Folhateen. Dis-

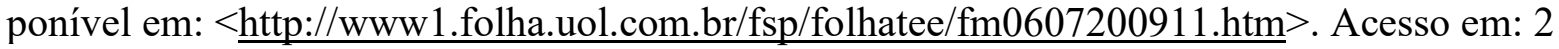
maio 2018.

GEE, James Paul. Good video games and good learning. Wisconsin: University of Wisconsin-Madison. 2005, 5p. Disponível em:

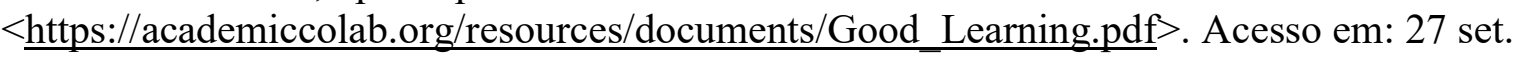
2018.

KELLER, John M. Development and use of the ARCS model of instructional design. Journal of instructional development. v. 10, no. 3, p. 2-10, 1987. Disponível em:

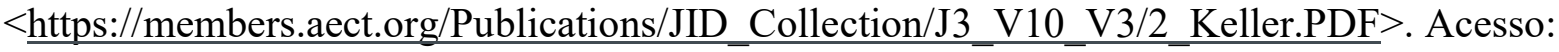
em: 15 dez. 2018.

KISHIMOTO, Tizuko Morchiba (Org.). Jogo,Brinquedo, Brincadeira e a Educação. 2. ed. São Paulo: Cortez, 1997.

LORENZONI, Marcela. Gamificação: o que é e como pode transformar a aprendizagem.

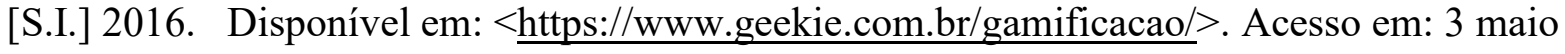
2018.

MATTAR, João. Games em educação. Como os nativos digitais aprendem. 1. ed. São Paulo: Pearson, 2010, 208p.

MOREIRA, Adelson F. Ambientes de Aprendizagem no Ensino de Ciência e Tecnologia. Belo Horizonte: Cefet-MG, 2007. 
PARODI, Karin. Engajamento: o grande desafio das organizações. Harvard Business Review. [S.I.] 2015. Disponível em: $<$ https://hbrbr.uol.com.br/engajamento-o-grande-desafiodas-organizacoes/>. Acesso em: 18 nov. 2018.

PIMENTA, Janice G. A importância dos jogos e brincadeiras na educação infantil. Dissertação (Mestrado) - Universidade Cândido Mendes, 2011. Disponível em:

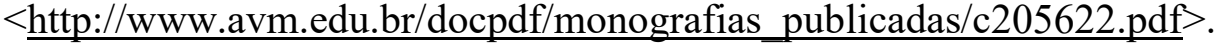

PRENSKY, Marc. Conjectura. v. 15, n. 2, mai/ago. 2010. Disponível em: $<$ http://www.ucs.br/etc/revistas/index.php/conjectura/article/viewFile/335/289>. Texto original disponível em: $<\mathrm{http}: / / \mathrm{www}$.marcprensky.com/writing/PrenskyThe_Role_of_Technology-ET-11-12-08.pdf>. Acesso em: 15 fev. 2019.

SQUIRE, Kurt D. Replaying history: learning world history through playing Civilization III. 1. ed. Indiana: Indiana University, 2004, 438p.

Education concept. FreepikDisponível em: $<$ https://www.freepik.com/freevector/colorful-education-concept-with-flat-design_2803973.htm>. Acesso em: 10 nov. 2018. Jogo.Wikipedia. Wikipedia.org Disponível em:

$<$ https://pt.wikipedia.org/wiki/Jogo>. Acesso em: 26 jan. 2019.

Kids are learning computer skills before life skills.Disponível em:

<http://www.avgdigitaldiaries.com/post/5452843104/digital-diaries-kids-are-learningcomputer-skills $>$. Acesso em: 10 fev. 2019.

. MMORPG.Dictionary. Dictionary.com Disponível em:

$<$ https://www.dictionary.com/browse/mmorpg $>$. Acesso em: 4 jul. 2018. 